\title{
Development of Report Turnaround Times in a University Department of Radiology during Implementation of a Reformed Curriculum for Undergraduate Medical Education
}

\author{
Die Entwicklung von Befundungszeiten im Rahmen der \\ Umstellung auf einen Modellstudiengang in einer \\ Universitätsradiologie
}

Authors

Liane Albrecht ${ }^{1}$, Martin H. Maurer ${ }^{2}$, Tim Seithe ${ }^{1}$, Joachim Braun ${ }^{1}$, Richard Gummert ${ }^{1}$, Jonas Auer ${ }^{1}$, Keno Sponheuer ${ }^{1}$, Tobias Philipp Meyl ${ }^{3}$, Bernd Hamm ${ }^{1}$, Maximilian de Bucourt ${ }^{1}$

Affiliations

1 Department of Radiology, Charité - University Medicine Berlin, Germany

2 Department of Diagnostic, Interventional and Pediatric Radiology, Inselspital Bern, Switzerland

3 Medical Department, Division Medical Strategy, Inselspital Bern, Switzerland

Key words

turnaround time, workload, quality management, workflow analysis, reformed curriculum for undergraduate medical education

received 20.04.2017

accepted 01.08.2017

Bibliography

DOI https://doi.org/10.1055/s-0043-118482

Published online: 21.9.2017

Fortschr Röntgenstr 2018; 190: 259-264

(c) Georg Thieme Verlag KG, Stuttgart · New York

ISSN 1438-9029

Correspondence

PD Dr. med. Maximilian de Bucourt, Dipl. Vw.

Department of Radiology, Charité - University Medicine

Berlin, Charitéplatz 1, 10117 Berlin, Germany

Tel.: ++49/30/450627085

Fax: ++49/30/4507627085

lianealbrecht@gmx.de

\section{ZUSAMMENFASSUNG}

Fragestellung Im Rahmen der Umstellung auf einen Modellstudiengang kommt es zur Verlagerung der Lehre aus den Vorlesungssälen in Kleingruppenunterricht unter anderem am Krankenbett. Ziel dieser Studie war es, herauszufinden ob unter vermehrtem Lehraufwand eine Zunahme der radiologischen Befundungszeiten (der Zeit vom Ende der Untersu- chung bis zur Erstellung des Befundes) in der Vorlesungszeit zu beobachten ist oder es zu vermehrten ungeplanten Abwesenheiten der radiologischen Kollegen kommt.

Material und Methoden Es erfolgte eine Analyse der Datenbank aller radiologischen Untersuchungen eines großen deutschen Universitätsklinikums im Zeitraum vom Wintersemester 2011 - 12 bis zum Sommersemester 2013. Dabei wurden 192984 radiologische Untersuchungen eingeschlossen und bezüglich Untersuchungszeitpunkt in oder außerhalb Vorlesungszeit sowie der Befundungszeit analysiert. Es erfolgte eine Unterscheidung zwischen Intensiv- und Normalstationen. Des Weiteren wurde der Dienstplan des gleichen Zeitraumes bezüglich des Lehraufwandes, der Urlaubs-, und Fortbildungs- und ungeplanten Ausfalltage ausgewertet.

Ergebnisse Im betrachteten Zeitraum kommt es zu einer Zunahme der Lehre von 1,75 Stunden/Tag im Wintersemester 2011 - 12 zu 6,49 Stunden/Tag im Sommersemester 2013 und in der vorlesungsfreien Zeit von 0,10 Stunden/Tag im Wintersemester 2011 - 12 zu 0,71 Stunden/Tag im Sommersemester 2013. Es zeigte sich eine Zunahme der Befundungszeit im betrachteten Zeitraum $(p<0,05)$. Die Befundungszeit war allerdings in der Vorlesungszeit geringer als in der vorlesungsfreien Zeit $(p<0,05)$. Auf Intensivstationen gab es keinen signifikanten Unterschied der Befundungszeiten zwischen Vorlesungszeit und vorlesungsfreier Zeit, eine Zunahme der Befundungszeit über den gesamten Zeitraum konnte allerdings auch hier gefunden werden. Es konnten keine vermehrten Ausfalltage in der Vorlesungszeit beobachtet werden.

Schlussfolgerung Insgesamt kommt es zu einer Zunahme der Befundungszeiten im betrachteten Zeitraum während der Implementation des neuen Modellstudienganges. Da dies aber sowohl in der Vorlesung- als auch in der vorlesungsfreien Zeit beobachtet werden kann, scheint die vermehrte Lehrtätigkeit nicht der einzige Grund zu sein. 


\section{Kernaussagen:}

- Digitale hochquantitativ erfassbare Parameter können in der Radiologie zur Evaluation von Arbeitsabläufen genutzt werden.

- Befundungszeiten lassen sich als ein Kriterium zur Beurteilung effizienten Personalmanagements heranziehen.

- Die Erfassung und Evaluation von Parametern wie Befundungszeiten können auf eine effizientere Ressourcenallokation hinwirken, indem sie Hinweise auf veränderte Rahmenbedingungen und veränderte Arbeitsintensitäten geben können, und/oder Kapazitätsreserven aufdecken welche möglicherweise nicht unmittelbar ersichtlich sind.

- Während der Umstellung auf einen deutlich lehrintensiveren Modellstudiengang Medizin konnte im betrachteten Zeitraum eine Zunahme der Befundungszeit verzeichnet werden, welche auf Intensivstationen nicht signifikant war.

- Da im betrachteten Zeitraum die Zunahme der Befundungszeit sowohl in der vorlesungsfreien Zeit als auch in der Vorlesungszeit zu konstatieren ist, kann die Einführung eines deutlich lehrintensiveren Modelstudienganges nicht als alleiniger Grund herhalten.

\section{ABSTRACT}

Purpose The implementation of a reformed curriculum for undergraduate medical education with a problem-oriented focus and more bedside teaching in small groups increases the academic teaching workload. The aim of this study was to investigate whether this increase in teaching duties is associated with an increase in report turnaround times of radiologists or increased unplanned absence during term times compared with term breaks (lecture-free periods) and over the whole period under investigation.

Materials and Methods The database of all radiological examinations performed at a large German university hospital was retrospectively analyzed for a two-year period from the winter term 2011/12 to the summer term 2013. A total of 192984 radiological examinations performed during this period were included in an analysis of reporting times (i.e., time from end of examination to completion of report) during term times versus term breaks. Reporting times were analyzed for all radiological examinations and for intensive care unit (ICU) patients. In addition, radiologists' schedules were analyzed in terms of teaching duties, unplanned absence, vacation days, and days away from work for education and training.
Results During the period under investigation, the teaching load increased from overall 1.75 hours/day in the winter term 2011/12 to 6.49 hours/day in the summer term 2013 and in the term break from overall 0.10 hours/day in the winter term $2011 / 12$ to 0.71 hours/day in the summer term 2013. Reporting time increased during this period $(p<0.05)$ but remained shorter during term times than during term breaks. The difference between term and term break for ICU patients was not significant. There was no increase in unplanned absences during term times.

Conclusion Overall, radiologists' reporting times increased during the period when the reformed curriculum for undergraduate medical education was implemented. As this was observed both during term and during term breaks, increased teaching duties alone cannot serve as a sole causal explanation.

\section{Key Points:}

- Digital high-quantitative parameters can be used to evaluate workflow in radiology.

- Reporting time can be a criterion for efficient staffing.

- The acquisition and evaluation of parameters such as reporting times could lead to a more efficient resource allocation by providing hints of changed framework conditions and changing working intensities and/or capicity reserves which may not be immediately apparent.

- During the period under investigation with the implementation of a teaching-intensive reformed curriculum for undergraduate medical education there was an increase in reporting time, which was not significant in intense care units.

- Since during the period under investigation the increase in reporting times can be stated both during term time and in the lecture free period, the implementation of the reformed curriculum for undergraduate medical education alone cannot serve as a sole causal explanation.

\section{Citation Format}

- Albrecht L, Maurer MH, Seithe T et al. Development of the Report Turnaround Times in a University Department of Radiology during Implementation of a Reformed Curriculum for Undergraduate Medical Education. Fortschr Röntgenstr 2018; 190: 259-264

\section{Introduction}

The duties of a university hospital go beyond general patient care and always include academic teaching and research. While in the past the teaching of medical students mostly relied on lectures, much of medical teaching today is done in small groups and requires more staff resources. Radiologists play a crucial role in this new type of medical education as their specialty represents a cross-section of many clinical specialties and state-of-the-art imaging findings can serve to illustrate many pathologies. This changing attitude is reflected in the amended German Ordinance for the Licensing of Physicians which became effective in 2002 and provides for more practical training in medical studies. This shift has been implemented in a catalog of learning objectives developed by the German Society for Medical Education (Gesellschaft für medizinische Ausbildung - GMA) [1] and the National Competence-Based Catalogues of Learning Objectives for Undergraduate Medical Education [2]. 
Studies have shown that case-based learning in small groups is much more effective than traditional approaches. It imparts more knowledge and also promotes teamwork, the development of leadership competence, and better conflict resolution skills [3]. Moreover, students learn to see the whole patient and are better prepared for their later professional life [4]. Practical exercises improve learning outcome and are preferred by students [5]. Role play - another form of practical education - allows students to train and improve communication and clinical examination skills in a protected environment [6].

Finally, there is bedside teaching, which actively involves patients in teaching. Patients show a positive attitude toward students when bedside teaching is done in small groups. Therefore, bedside teaching classes should ideally involve only a very small number of students. Patients prefer the presence of not more than 8 students with only 2 of them examining [7]. Articles on the art of bedside teaching emphasize as one of its advantages that students learn to use a language that is understood by patients. Although bedside teaching requires more time for preparation, it is beneficial for patient management and teaching [8-10]. Students having attended bedside teaching courses fare better in practical tests [11]. In the field of radiology it has been shown that students learning ultrasound at the bedside have both better theoretical knowledge and practical skills [12].

In the winter term 2010/11, a reformed curriculum for undergraduate medical education (Modellstudiengang Medizin) was introduced at Charité - University Medicine Berlin, placing a greater focus on the teaching of practical skills in addition to theoretical knowledge. This was primarily done by introducing new teaching formats such as $\mathrm{POL}$ groups ( $\mathrm{POL}=$ problem-oriented learning) and $\mathrm{CIT}$ courses ( $\mathrm{CIT}=$ communication, interaction, and teamwork) [13].

This study investigates whether the increased teaching load associated with the implementation of this reformed program has an effect on how physicians handle their clinical work.

\section{Materials and Methods}

A retrospective comparison of the reporting times for all radiological examinations conducted at Campus Charité Mitte was performed in the period from Oct. 17, 2011 through Oct. 11, 2013 during the teaching periods of the summer and winter terms (term time) and the periods where no classes take place (term break). Campus Charité Mitte is one of the three sites of Charité - University Medicine Berlin. In total, there are 3000 hospital beds at the three sites, with 870 of those beds being at the teaching-centric Campus Charité Mitte. The total number of enrolled medical students is 7000 , with 700 of those being new undergraduate medical students per year [14].

During this two-year period, the teaching load increased due to the implementation of a reformed medical curriculum for undergraduate medical education, and there was a general increase in the number of patients requiring care. The parameters measured to determine whether routine patient care suffered because of the increased teaching duties or whether the radiologists' workload increased appreciably or measurably were reporting times and unplanned absence (due to e.g. illness or other unexpected events). Reporting time was defined as the time from the end of the examination to the first finalized written report (note: the time until final release by a supervisor was not chosen as it may induce a bias due to different reporting time release speeds of different supervisors). Unplanned absence, especially due to illness, was selected as a measuring tool, to evaluate whether a greater workload may increase this variable (e. g. due to more stress). These parameters were compared between term times and term breaks (lecture-free periods) over the two-year study period.

Reporting times were analyzed using data retrieved from the digital database (Centricity RIS-i 4.2 Plus, GE Medical Systems, Milwaukee, WI, USA). The database provided information on the following pseudonymized parameters:

- Pseudonymized information (random ID code; age; ZIP code; city; mode of hospital admission)

- Times (scheduled examination time; patient arrival; beginning and end of examination; report; release of report [each with date and time in the following formats: DD.MM.YYYY and $\mathrm{HH}$ : $\mathrm{MM}: \mathrm{SS}]$ )

- Reporting physician (person dictating or writing), releasing physician

- Type of examination

- Requesting physician; accounting center; unit; workplace

The database was analyzed using Excel2013 for Windows (Microsoft, Redmond, CA, USA). Reporting time was defined as the interval from the end of the examination until the first written report was available, calculated as the difference of the columns [Report] - [End of examination]. The Excel INT function was used to remove the date from the result. The result was converted into minutes. The calculated reporting times were assigned to one of three time intervals: (1) weekdays during term; (2) weekdays during term break; and (3) weekends and public holidays. Term time included the 14 weeks during which classes take place plus the examination week; while the term break included the remaining weekdays. The hours spent on academic teaching were retrieved from the work schedules of the radiologists taking into account absences (unplanned absences like illness, vacation, education and training).

\section{Patients}

All examinations/procedures for which reports were written and which were performed on weekdays during the period under investigation were included. This also included procedures not constituting routine patient examinations (demonstrations, research examinations, and procedures for equipment testing) in order to compute the clinical workload of radiologists as accurately as possible.

All examinations/procedures that took place on weekends and public holidays or procedures for which no reports were created (e. g., datasets from external examinations imported into the department's database) were excluded. This resulted in a total number of examinations/procedures performed at the department during the two-year study period of 192984 ( $\vee$ Table 1). 
- Table 1 Reporting times and number of examinations per day for the period from winter term (WT) 2011/12 to summer term (ST) 2013.

- Tab. 1 Befundungszeiten und Untersuchungszahlen für den betrachteten Zeitraum vom Wintersemester 2011/12 bis zum Sommersemester 2013.

\begin{tabular}{|c|c|c|c|c|c|c|c|c|c|c|}
\hline & \multicolumn{5}{|c|}{ all examinations } & \multicolumn{5}{|c|}{ examinations of ICU patients } \\
\hline & \multicolumn{2}{|c|}{$\begin{array}{l}\text { reporting time in } \\
\text { minutes }\end{array}$} & \multirow[b]{2}{*}{ p-value } & \multicolumn{2}{|c|}{$\begin{array}{l}\text { no. of examinations } \\
\text { per day }\end{array}$} & \multicolumn{2}{|c|}{$\begin{array}{l}\text { reporting time in min- } \\
\text { utes }\end{array}$} & \multirow[b]{2}{*}{ p-value } & \multicolumn{2}{|c|}{$\begin{array}{l}\text { no. of examinations } \\
\text { per day }\end{array}$} \\
\hline & term & break & & term & break & term & break & & term & break \\
\hline WT $11 / 12$ & 42.05 & 56.33 & $<0.05$ & 356.7 & 427.7 & 34.43 & 40.90 & $<0.05$ & 29.5 & 30.9 \\
\hline ST 12 & 48.75 & 46.37 & 0.1 & 378.4 & 397.6 & 40.23 & 32.86 & $<0.05$ & 29.4 & 27.7 \\
\hline WT $12 / 13$ & 45.58 & 58.43 & $<0.05$ & 381.3 & 434.8 & 44.89 & 49.22 & 0.96 & 30.1 & 28.1 \\
\hline ST 13 & 49.88 & 60.32 & $<0.05$ & 365.0 & 375.9 & 46.10 & 46.18 & 0.92 & 28.4 & 28.8 \\
\hline overall & 46.45 & 54.80 & $<0.05$ & 370.3 & 406.2 & 40.80 & 41.13 & 0.56 & 29.6 & 28.8 \\
\hline
\end{tabular}

The new reformed curriculum consists of large formats such as lectures and new small group formats. Every time a patient is included, the number of students is limited to 4 . Classes for practical training without contact to patients are limited to 8 students (POL - problem orientated learning). Special classes to learn communication, interaction and teamwork are limited to 16 students. Teaching is performed by every radiologist. Every lecture, seminar or course requires the full time attendance of the teachers [15]. In the beginning of the period under investigation, the third class started with the reformed curriculum. The teaching duties in the term breaks are classes for elective students and student apprentices.

\section{Analysis and Statistical Tests}

Statistical and graphic analysis was performed using OriginPro 9.1G for Windows (OriginLab Corporation, MA, Northhampton, USA). Median values were used for analysis as otherwise nonnormal distribution of data would distort the results.

All tests were performed with a significance level of 0.05 and a $95 \%$ confidence interval. Normal distribution was ruled out using the Shapiro-Wilk test (up to 5000 variables) or the KolmogorovSmirnov test (over 5000 variables). Variations in reporting times between the four terms under investigation were tested using the Mann-Whitney U-test (nonparametric test for independent samples) and the Kruskal-Wallis ANOVA (nonparametric test for several independent samples).

\section{Results}

Overall, the reporting time during the 2-year study period was on average 46.45 min during term time and 54.80 min during term breaks ( $\triangleright$ Table 1 ). Fewer examinations took place during term time versus term breaks (370.6/day versus 406.2/day, see - Table 1).

Analysis of reporting time for ICU patients revealed no significant difference: 40.80 min for term time and 41.13 min during term breaks. There was no significant difference in the number of examinations per day, 29.6/day in the term time and 28.8 /day in the break time.

The results also show that, over the two-year study period, reporting time increased both during term and term breaks. This observation applies to all examinations as well as examinations of ICU patients ( $\triangleright$ Fig. 1 ).

The average number of time spent teaching per day increased from 1.75 hours/day in the winter term 2011/12 to 6.49 hours/ day in the summer term 2013 ( $\triangleright$ Table 2). However, there was also an increase in teaching hours during term breaks from 0.10 hours/day at the beginning of the study period to 0.71 hours/day at the end of the study period ( $\triangleright$ Fig. 2 ).

The total number of unplanned days absent from work during the 2-year study period was consistently higher during term breaks than during term times, and there was no increase over the study period ( $\vee$ Fig. $\mathbf{3}$ ). The difference was significant for the winter terms only.

Vacation times were highest during summer term and most vacation was spent during term break (as required in the work contracts for academic staff). During winter terms, vacation was more common during term times ( $\triangleright$ Fig. 3 ). The difference is significant only for summer term.

Days off from work for advanced training and research coincide with the large radiological congresses (Radiological Society of North America, RSNA, and German Congress of Radiology, DRK, during term times, and European Congress of Radiology, ECR, during term breaks). As a result, more days tend to be taken off during term time rather than during term breaks ( $\triangleright$ Fig. 3 ). This difference was significant $(p<0.05)$ for all term breaks versus all term times as well as for the comparison of each term time with the respective term break.

\section{Discussion}

Overall, the results of the retrospective analysis presented here indicate that reporting times increased during the study period both during term times and during term breaks. Therefore, it is 
- Table 2 Work schedule analysis over the two-year study period from winter term (WT) 2011/12 to summer term (ST) 2013.

- Tab.2 Dienstplanauswertung für den betrachteten Zeitraum vom Wintersemester 2011/12 bis zum Sommersemester 2013.

\begin{tabular}{|c|c|c|c|c|c|c|c|c|}
\hline & \multirow{2}{*}{\multicolumn{2}{|c|}{$\begin{array}{l}\text { teaching } \\
\text { (hours/day) }\end{array}$}} & \multirow{2}{*}{\multicolumn{2}{|c|}{$\begin{array}{l}\text { unplanned absence } \\
\text { (staff/day) }\end{array}$}} & \multirow{2}{*}{\multicolumn{2}{|c|}{$\begin{array}{l}\text { vacation } \\
\text { (staff/day) }\end{array}$}} & \multirow{2}{*}{\multicolumn{2}{|c|}{$\begin{array}{l}\text { advanced training } \\
\text { (staff/day) }\end{array}$}} \\
\hline & & & & & & & & \\
\hline & term & break & term & break & term & break & term & break \\
\hline WT $11 / 12$ & 1.75 & 0.10 & 0.56 & 1.13 & 3.12 & 2.53 & 0.21 & 0.70 \\
\hline ST 12 & 4.75 & 0.19 & 1.13 & 1.36 & 3.51 & 5.29 & 1.41 & 0.46 \\
\hline WT 12/13 & 6.55 & 0.58 & 1.07 & 1.61 & 3.69 & 3.20 & 2.43 & 0.73 \\
\hline ST 13 & 6.49 & 0.71 & 0.81 & 0.88 & 4.03 & 5.69 & 1.29 & 1.61 \\
\hline overall & 4.87 & 0.38 & 0.89 & 1.17 & 3.58 & 4.15 & 1.33 & 0.85 \\
\hline
\end{tabular}

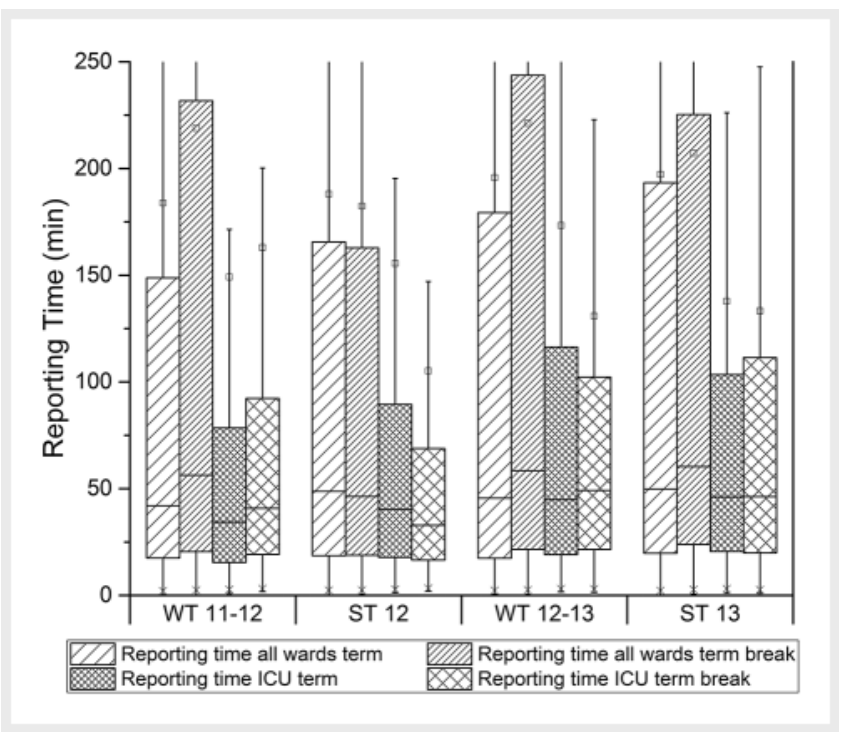

- Fig. 1 Development of reporting times from the winter term $2011 / 12$ to the summer term $2013(n=192984)$.

Abb. 1 Entwicklung der Befundungszeiten vom Wintersemester 2011/12 bis zum Sommersemester 2013 ( $n=192984)$.

questionable whether this development can be attributed to an increase in teaching duties, particularly since less than one hour per day was spent teaching during term breaks in the study period. In an earlier study at our department, it was shown that reporting times decreased without any apparent reason in the interval before the two-year period investigated here, suggesting that general and other variations in reporting times (such as changes in workflow, staff quantity and quality/stage of specialist training, and technical advances) must be taken into account [16]. The nominal amount of staff was constant throughout the investigation period, but the quality, efficacy and efficiency (due to change in experience, especially during residency rotation and accumulation knowledge and radiological skills) remain variable as new colleagues join the team and elder colleagues leave.

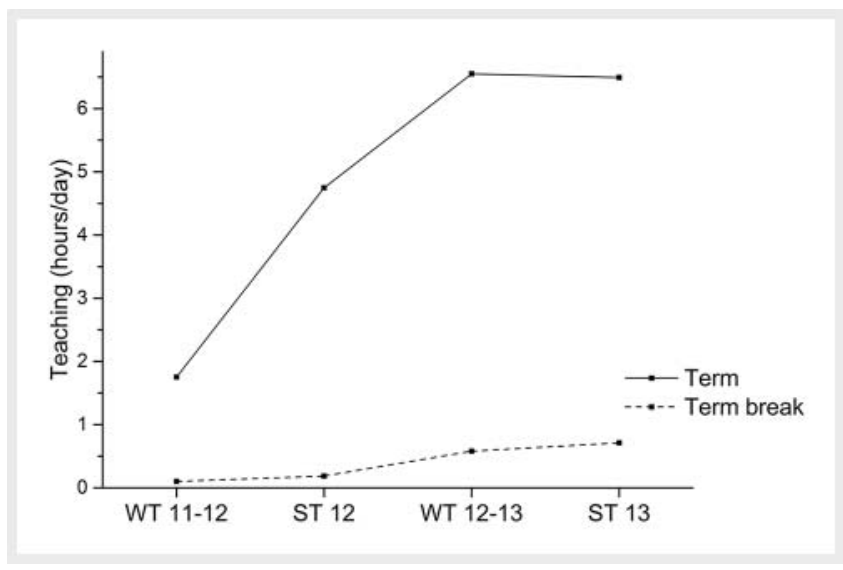

- Fig. 2 Development of hours spent teaching per day from the winter term 2011/12 to the summer term 2013.

- Abb. 2 Entwicklung der für die Lehre aufgewendeten Stunden pro Tag vom Wintersemester 2011/12 bis zum Sommersemester 2013.

During the study period unplanned absences varied but there was no general increase. Moreover, loss of workdays was greater during term breaks compared with term times, suggesting that the increase in teaching duties is compensated for in ways not reflected in the parameters investigated here. However, it must also be kept in mind that there are multiple reasons for unplanned absence from work. Besides the workload and an increase in teaching duties as investigated here, other reasons may include the severity of seasonal cold epidemics and other factors. Also, conversely, it may be possible to regard teaching duty as a strong factor for going to work (e.g. even with a light illness) as it may be difficult to find prepared teaching colleagues to substitute on short notice.

Our observations suggest that the higher teaching load is compensated for by a lower number of examinations performed per day during term times, suggesting that more elective procedures may be planned in greater quantities during term breaks. Moreover, staff is encouraged to take vacation during term 


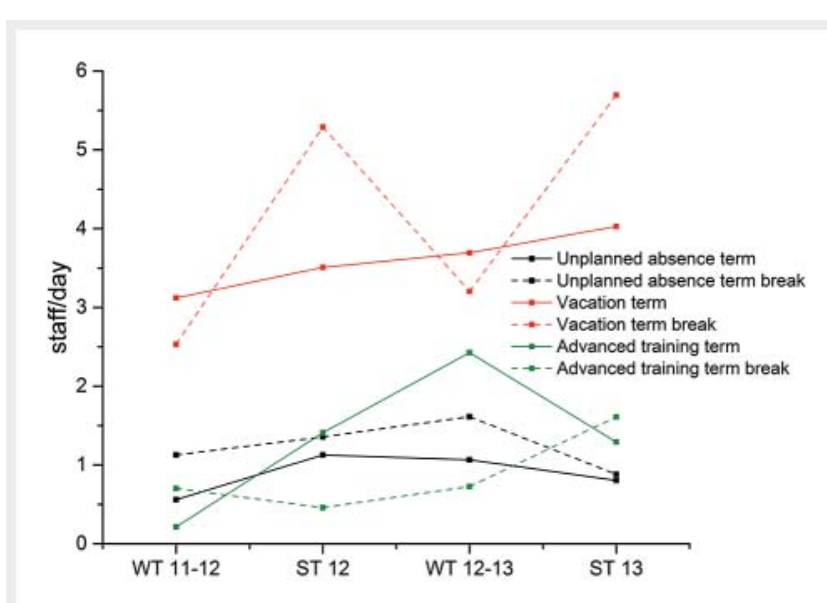

- Fig. 3 Development of unplanned absence, vacation and advanced training from the winter term $2011 / 12$ to the summer term 2013.

- Abb. 3 Entwicklung der Urlaubs-, Fortbildungs- und ungeplanten Ausfalltage vom Wintersemester 2011/12 bis zum Sommersemester 2013.

breaks. However, our results show that the number of examinations of ICU patients is similar during term times and term breaks, indicating that management of emergency patients is not impaired by an increased teaching load.

A limitation of this analysis is that the time it takes to prepare for academic teaching is not included as this time does not appear in work schedules. Investigators emphasize that the success of bedside teaching classes relies on good preparation, structuring, and adequate selection of cases $[8,17]$. This implies that the actual time required for teaching is likely much greater than reflected in our analysis. But we saw an increase in education and training over the two-year period. This may reflect the higher teaching requirements demanded by the National Competence-Based Catalogues of Learning Objectives for Undergraduate Medical Education.

During the period investigated in the present study, the architectural reconstruction of the Charite main building at Campus Mitte required a few rooms of the Department of Radiology to be moved which may have impaired workflow to a minor extent. Full implementation of the reformed curriculum for undergraduate medical education at the Charité is still underway and it is therefore expected that the teaching load will increase further once all medical students are enrolled in the new reformed program. Further investigation in the future appears of interest, and future studies should also include other specialties.

Nevertheless, all departments in university hospitals will have to deal with increased teaching duties to comply with the National Competence-Based Catalogues of Learning Objectives for Undergraduate Medical Education. It is certain that this will interfere with clinical duties and it is very important to validly detect the time when it becomes a necessity to adjust the amount of staff of the department.

\section{Conflict of Interest}

The authors declare that they have no conflict of interest.

\section{References}

[1] Schnabel KP, Boldt PD, Breuer G et al. A consensus statement on practical skills in medical school - a position paper by the GMA Committee on Practical Skills. GMS Z Med Ausbild 2011; 28: Doc58

[2] V. MMFdBDe. Nationaler Kompetenzbasierter Lernzielkatalog Medizin. 2015. [updated 2015; cited 30/06/17]; Available from: http://www. nklm.de/files/nklm_final_2015-07-03.pdf

[3] Lerner S, Magrane D, Friedman E. Teaching teamwork in medical education. Mt Sinai J Med 2009; 76 (4): 318 - 329

[4] Thistlethwaite JE, Davies D, Ekeocha $S$ et al. The effectiveness of casebased learning in health professional education. A BEME systematic review: BEME Guide No. 23. Med Teach 2012; 34: e421 - e444

[5] Mileder L, Wegscheider T, Dimai HP. Teaching first-year medical students in basic clinical and procedural skills-a novel course concept at a medical school in Austria. GMS Z Med Ausbild 2014; 31: Doc6

[6] Luttenberger K, Graessel E, Simon C et al. From board to bedside training the communication competences of medical students with role plays. BMC Med Educ 2014; 14: 135

[7] Alawad AA, Younis FH. Patients' Attitude towards Undergraduate Medical Students at University Charity Teaching Hospital in Sudan. Int J Med (Dubai) 2014; 2: 28-31

[8] Gonzalo JD, Heist BS, Duffy BL et al. The art of bedside rounds: a multicenter qualitative study of strategies used by experienced bedside teachers. J Gen Intern Med 2013; 28: 412-420

[9] Janicik RW, Fletcher KE. Teaching at the bedside: a new model. Med Teach 2003; 25: $127-130$

[10] Peters M, Ten Cate O. Bedside teaching in medical education: a literature review. Perspect Med Educ 2014; 3: 76-88

[11] Roberts L, Lu WH, Go RA et al. Effect of bedside physical diagnosis training on third-year medical students' physical exam skills. Teach Learn Med 2014; 26: 81-85

[12] Blackstock U, Munson J, Szyld D. Bedside ultrasound curriculum for medical students: report of a blended learning curriculum implementation and validation. J Clin Ultrasound 2014; 43: 139-144

[13] Modellstudiengang Medizin. 2015. [updated 2015; cited 17/03/17]; Available from: http://www.charite.de/studium_lehre/studieren_an_der_charite/grundstaendige_studiengaenge/modellstudiengang_ medizin/

[14] Qualitätsbericht Charité. 2012. [cited 30/06/17]; Available from: https://www.charite.de/diecharite/mediathek/publikationen/

[15] Studienordnung des Modellstudiengangs Medizin der Charité Universitätsmedizin Berlin. [cited 30/06/17]; Available from: https://www.charite.de/fileadmin/user_upload/portal/studium/Prodekanat_fuer_Studium_und_Lehre/StudienordnungModellstudiengangMedizin.pdf

[16] Albrecht L, Busse R, Tepe $\mathrm{H}$ et al. Turnaround time for reporting results of radiological examinations in intensive care unit patients: an internal quality control. Radiologe 2013; 53: 810-816

[17] Stickrath C, Aagaard E, Anderson M. MiPLAN: a learner-centered model for bedside teaching in today's academic medical centers. Acad Med 2013; 88: 322-327 